\title{
LIMITATIONS IN THE AIRSPACE SOVEREIGNTY OF STATES IN CONNECTION WITH SPACE ACTIVITY
}

\author{
Prof. Małgorzata POLKOWSKA, PhD \\ m.polkowska@akademia.mil.pl \\ Faculty of National Security \\ War Studies University, Warsaw, Poland
}

\begin{abstract}
:
The launch of the Soviet Sputnik in 1957 resulted in the emergence of two legal concepts concerning spaceflight. The first of them concerned harmless passage through airspace subjected to the sovereignty of states, the second - recognition that at the height of the trajectory of a passage, space is no longer subject to the sovereignty of states (res omnium communis). In both cases, we are dealing with limiting the sovereignty of states. These issues have not been resolved to this day. The practice of spaceflight has confirmed the freedom of spaceflight, although it has not resolved the issue of the upper limit of airspace. It is worth emphasising, however, that the decisive factor for the development of space law was the customary law that arose in 1957, because states did not protest and tacitly accepted the principle of a harmless flight.
\end{abstract}

Keywords: sovereignty, space, state, space law, boundary

\section{Introduction}

The concept of "space of flights", especially after the appearance of motor aviation at the turn of the 19th and 20th centuries, began to create many legal problems. On the one hand, it was established that space that is used for aviation purposes and which is subject to the sovereignty of the state is called "air space" or "atmospheric space" (as opposed to upper or non-atmospheric space). The skies begin where This work is licensed under the Creative Commons Attribution-NonCommercial-NoDerivatives 4.0 License. 
the upper limit of the airspace lies. However, international law does not regulate the issue of the location of the upper limit of airspace. The Chicago Convention of 1944, recognising the sovereign rights of states in their airspaces, does not define the boundaries of this space. Likewise, the annexes to the Chicago Convention do not deal with legal relations relating to non-atmospheric space (McDougal, Lasswell and Vlasiĉ 2007, Wassenbergh 1978, Johnson 1974, Kayser 1995, Martin 1968, Homburg 1965).

On the other hand, looking for the most general assumptions that could determine the legal situation of space (outer space), it was noted that the main goal of the coexistence of the states of the world is respect for the principle of sovereign equality. Among these assumptions, the principle of res communis seemed the most appropriate, for which a large group of researchers spoke. According to this principle, each and every state in the world can use space. From an Earth-related point of view, transferring legal concepts to space and taking into account the possibility of not using space for Earth-related purposes, this principle must be understood in a more general manner and space defined as res communis omnis universi.

It can, therefore, be pointed out that before 1957, there were two main directions in contemporary law regarding upper space. According to the first of these, the state can extend its sovereign power and control to it. According to the second one, supra-space is considered a "common thing". Until the commencement of the space flight age, however, there were no clear decisions on this matter both in practice and in international agreements.

\section{The beginning of the space flight era (1957) and customary law}

Some authors, including N. Jasentuliyana, recognise that the science of space law was created with the launch of the first Sputnik in 1957 (at that time, the so-called Space Age began). Before the launch of the first artificial satellite, many publications and analyses were created which were connected with legal problems resulting from future human activity in space. Work on legal issues in connection with the technical and biological possibilities of using the upper layers of aboveground space inaccessible to humans at that time had already been undertaken in the 
interwar period by a Soviet scientist (E. A. Korowin). There was a large amount of literature on so-called space law in the US and Great Britain (JC Cooper, CW Jenks), Germany (A. Meyer, JL Kunz), France (E. Pepin, J. Kroell, RH Mankiewicz) and Italy (A. Giannini). After 1957, other Soviet scholars: G. Zadrożnyj, A. Galina, N. Ulianow, F. Kowalew, Czeprakow and G. Żukow dealt with this issue. In Polish science, the work of C. Berezowski, L. Babiński, J. Machowski, J. Sztucki and M. Żylicz is worth pointing out. The attitude of the governments of states to the principle of airspace freedom varied depending on the current political and economic situation. For example, at first, Britain was an advocate of the principle of state sovereignty, but after the First World War, the development of British aviation moved swiftly, and there were voices in Great Britain demanding the freedom of airspace. On the other hand, before the 1930s, the US spoke out for the freedom of the air for economic reasons, then they protected their closed skies, opening them to other states only in the case of mutual benefits. Among the numerous authors, who were supporters of the theory of the sovereignty of the state in the air space, the most extreme position was occupied by German authors (for example Zittelmann) (Berezowski 1957, pp. 168-170). Similarly, the homogenous, or more precisely, the undecided attitude of governments to the law of future spaceflight, was extended.

After the launch of the Sputnik in 1957, it turned out that the principle of usque ad coelum, providing for the sovereignty of the state over the airspace located above its territory, cannot be maintained in relation to the exploration of outer space. It has been noted that obtaining the consent of individual states to fly satellites and other devices that are in orbit over 100 miles above the Earth's surface would be extremely difficult. Therefore, after 1957, two concepts concerning the airspace sovereignty of the state emerged. In the first thought it was assumed that at the height of the spacecraft's trajectory, space is no longer subject to state sovereignty (res omnium communis). This would mean that the sovereignty of states over their airspace would be limited to a certain height on which this space borders outer space. It is difficult to say where the limit lies (Shaw 2000). In 1957, A. G. Haley formulated the thesis that space in the legal sense begins where the spacecraft, after leaving the area of air resistance, gets within range of the centrifugal force.

After 1957, some authors, including Soviet lawyer G. Zadorozhny, proposed introducing the principle of air freedom (analogically to the freedom of the High 
Seas) to a height of over 20-30 km above the ground. In 1960, another Soviet lawyer, G. Zhukov, decided that a contract should be negotiated limiting the vertical sovereignty of states at a relatively low level.

The second concept concerned the recognition of the sovereignty of the state in the airspace, limited by the right of innocent passage of spacecraft through air space. As claimed by C. Berezowski, against the concept that permits limiting sovereignty for international trade, one may argue that sovereignty cannot be limited because then it would cease to be supreme and unlimited power (Berezowski 1957, p. 178).

The exercise by the state of unlimited control and power in the air is a condition for the security of the state and its citizens, as well as for satisfying other important interests (Shrewsbury 2003, pp. 115-160). One cannot imagine its fulfilment in recognition of the universal right of an innocent flight. This security was therefore an essential argument in favour of the concept of territorial authority; economic interests were taken into account to a lesser extent. It seems, therefore, that air superiority, which, according to the terminology of aviation conventions, is called "full and exclusive sovereignty", manifests itself as the right of a state to prohibit or restrict flights of aircraft, in particular foreign ones, through its airspace and as a state's right to submit any aircraft flying through this space to its laws and authority (McDougal, Lasswell, Vlasiĉ 2007, pp. 9-14). It can be considered whether the same manifestations of authority apply to flights of non-aircraft in the classic sense. It seems that if one considers the total and exclusive sovereignty of states in airspace, no restrictions on this sovereignty can be presumed. Until there is evidence to the contrary, for the same reasons it should be considered as indivisible, manifesting itself both in relation to aircraft and in relation to other flying objects.

According to the Soviet scholars, Kovalev and Czepek, space flight is a flight of a body that has reached the minimum of a circular speed and moves on or around a closed orbit around the Earth, or in an open straight line, moving away from the ground or returning from such a flight. The admission of such a flight may take place while maintaining territorial authority in a given space. This is the issue, for example, in cases where states agree to fly foreign aircraft on the basis of unilateral contracts or permits (in the law of the sea, the innocuous flow of foreign vessels can be reconciled with the authority of the coastal state in territorial waters). Some 
authors, however, think that because, so far, it has not happened yet that any state would make a protest against the violation of its sovereignty in connection with the passage of a space object in airspace under its jurisdiction, we can find here the norm of common international customary law, the content of which is recognition of the admissibility of such flights, provided that such flights do not pose a threat to relevant, protected international interests, and in particular their security (Górbiel 1985, pp. 97-98).

The admission of artificial satellites only applies to cases in which these objects had a specific scientific-experimental purpose and, according to statements of states expelling space objects, they were not intended to harm other states. Thus, one can speak of an "almost harmless passage" intended for specific tasks of artificial space objects passing through territorial airspace and beyond. This does not mean, however, the exclusion of these objects from the sovereignty of the territorial state; nor can we draw any conclusions as to the upper limit of territorial airspace. If it is assumed that the principle of airborne scaffolding applies to all types of flying objects in this space, it must be concluded that each state may object to the passage of artificial space objects through its air territory, if it considers that it is harmful, flight conditions determined by its law and the control of its authorities. When it comes to the responsibilities of the territorial state, they may refer to ensuring control over artificial space objects flying in its airspace, prohibiting the transit of objects intended for tasks contrary to international law or prohibiting the release of such objects from its territorial space into the space of neighbouring states (Żylicz 1960, pp. 189-190).

According to M. Żylicz, the practice of states turned out to be important for the creation of a new law. The silent acceptance by states, without protest, of flights over their territories of artificial satellites of the Earth can be treated as a dayto-day establishment of a new rule of customary international law, according to which the state's supremacy does not extend to the height enabling artificial placement satellites in orbit. However, this agreement could also be interpreted as only allowing the harmless passage of satellites, without prejudging the status of the space they use, just as the right of innocent passage of foreign sea-going vessels through territorial waters is recognised. The law continues to develop not only in treaties, but also in customary law (Żylicz 1960). 
Summing up, one can point to two concepts that appeared in 1957. The first of them concerned harmless passage through airspace subjected to the sovereignty of states; the second, recognition that at the height of the trajectory of passage, space is no longer subject to the sovereignty of states (res omnium communis). In both cases, we are dealing with limiting the sovereignty of states. These issues from 1957 were not resolved. Thus, it can be assumed that the practice of 1957 later confirmed the freedom of spaceflight, although it did not resolve the issue of the upper limit of airspace. However, it is worth emphasising the importance of the fact that in 1957, states did not protest but tacitly accepted the principle of a harmless flight.

\section{The process of creating international space law}

The debate on defining the boundary between the sovereignty of the state in outer space and the vertical limitation of the sovereignty of the state has continued for decades (Apfel 1988, pp. 58-60). Due to the fact that there is no agreed delimitation between the territory of the state and free space, the state itself should define the limits of its vertical sovereignty. In fact, no state has done this so far. Meanwhile, this delimitation is important due to new technologies that allow various devices to perform operations at ever higher altitudes. In addition, the rapid development of space tourism and ensuring equal access to space require the establishment of this border (Reinhardt 2007, pp. 66-137, Hobe). It seems that setting a low limit of vertical sovereignty will allow the state using artificial satellites free access to space. However, even in outer space, states cannot act to the detriment of the interests of other states.

The doctrine of the law of non-atmospheric space in the earliest period of its history was directly connected with the science of international aviation law. This subject has become a field of interest for international (non-governmental) scientific organisations. Space activities from 1957 became more and more common. The number of states involved in the peaceful exploitation and exploration of space has increased significantly. The first organisations dealing with space issues began to appear. Work on the legal issue of extra-terrestrial space led, among others, by the Institute of International Law (IIL), International Law Association 
(ILA) and International Astronautical Federation (IAF), organising, among other things, numerous colloquia and scientific conferences on the legal issues of the sky (Górbiel 1985, pp. 17).

The process of forming space law began in 1958, when the UN General Assembly established a Committee on the Peaceful Uses of Outer Space (hereinafter: COPUOS). The Committee created two subcommittees, one legal and the other scientific-technical, to assist in their work. The UN recognised the need to maintain international peace and security and was intended to encourage the progressive development of international law and its codification. It was a turning point for international cooperation in space and for the development of international space law (Hermida 2004, p. 56).

The first significant step in the development of space law was taken in 1963, when the General Assembly adopted a Declaration of legal principles governing activities in the field of space exploration and use (Durys and Jasiński 1999, p. 228). This resolution gave rise to the Treaty of 1967 on the principles of operation of states in the field of research and use of outer space, including the Moon and other celestial bodies, the Outer Space Treaty (hereinafter: OST) (Journal of Laws of 1968 No. 14, item 82). COPUOS created the four remaining international treaties regulating human activity in space. In addition, a series of legal principles governing space activities (concerning, inter alia, direct satellite transmission, remote sensing and resources of nuclear power sources) was created (Jasentuliyana 1997, pp. 345-346).

The lack of an agreed limit on the vertical sovereignty of states caused problems related to state responsibility for activities in space (including an increasing number of complaints). Already in the Sxties, there was a need to define the limit of gas mass in free space and the limits of atmosphere use by objects at very high altitude. Defining these boundaries is not only the legal and technological sphere, but also the sphere of political interests (Fixel 1948, pp. 65). The problem with defining state vertical sovereignty results from the lack of a natural border separating airspace and space (Kuhn 1920, pp. 369-388). There are many different proposals for demarcation between air and space (COPUOS considers such a definition from 1967) and doubts as to whether such a demarcation should be carried out (the US is against it). There is no sharp boundary between air and space. 
When the USSR and the US were the first to start their expansion towards outer space, they tacitly assumed that international law did not prohibit it, and third countries did not protest. As a result, the common practice of freedom to explore and use space above the Earth's atmosphere has been adopted. Many researchers, including M. Markoff, write about the need to establish the boundary between airspace and space and disagree with the findings of the special UN Committee, which recognised in the Fifties that due to the then state of research and the needs of astronautics, the determination of this border was not necessary. Researchers recognise the need to define this limit due to the application of the principle of the exclusive and complete sovereignty of the state and the legal status of free space (Markoff 1969, pp. 9-39).

Neither the Chicago Convention of 1944 nor the OST treaty finally provide an answer to the question of the delimitation of the border of space and air, and do not define the very concept of outer space. Different definitions have appeared. The functional concept was based on the assumption that not only the term "space", but also the concept of "space activity" (or "spaceflight"), requires the law of international definition, regardless of where the activity takes place. A theorem was also proposed, according to which the strict definition of the term "space" is impossible to prepare at the present stage of astronautics development, and hence should be postponed until the future, until a time when there is more extensive knowledge of space technology as well as the greater possibility of its practical use.

In 1959, The UN General Assembly recognised that the issue of creating a definition was not urgent. It was a question of time as to when such a definition becomes the norm of international customary law. The Assembly, however, recommended the space committee to "work actively" on the issue of the definition of nonatmospheric space. In 1967, two French and Canadian documents were accepted, among others, at the UN Scientific and Scientific Session of COPUOS. The French proposed that work should be undertaken not only on the definition of space (suggesting that it extends for more than $80 \mathrm{~km}$ above the ground), but also on the definition of space activity. The Canadian document proposed adoption as the starting point for searching for the optimal formula of $100 \mathrm{~km}$ altitude delimitation, corresponding to a hundredth of the distance between the equator and the pole (measured along the Earth's surface), or $64 \mathrm{~km}$, corresponding to a hundredth of the Earth's radius. 
In the COPUOS report from 2007, however, it was recognised that due to the difficulties in reaching a compromise on the definition of delimitation and space, Member States should continue to consult on the maintenance of peace and security in space and promote the principle of peaceful use of space.

The issue of space law was also the subject of a plenary debate in 1956 in the International Civil Aviation Organization (ICAO) for the first time. In its report to the $10^{\text {th }}$ Session of the ICAO General Assembly in Caracas, the ICAO Council raised the issue of the organisation's interest in space issues and the Council's competence in relation to state-led activities in space. Initially, the ICAO also tried to get involved in the work on space law; some researchers claimed that the 1944 Chicago Convention could be supplemented with articles on space navigation or at least used to construct a space agreement. In 1959, at the $12^{\text {th }}$ ICAO Assembly, it was recognised that the Legal Committee should join the space work that was already at the UN (peaceful use of space).

\section{The internal regulation of states}

Regardless of the interpretation of certain elements of customary law, created immediately after 1957, for the further development of space law, it went towards the recognition of outer space as a "common good". By dropping the claims arising from territorial sovereignty, states took action to achieve common goals. In the internal legislation of some states, there is a concept of limiting sovereignty in airspace. In 2002, Australia began reform of the National Airspace System (NAS), based on international standards (such as in the US), but with a defined upper airspace limit of 60,000 feet $(18.3 \mathrm{~km})$ as a class A space. For Australia's Space Activities Act in 1998, it defined the space object as operating at an altitude of over $100 \mathrm{~km}$ above sea level. These acts, however, do not mean that Australia waives any claim of sovereignty that it may have to an area of over $60,000 \mathrm{~km}$. In 1961, Germany changed its Air Navigation Act from 1959 to include spacecraft and rockets in the definition of an aircraft. However, German law does not define the upper part of airspace.

Before 1957, lawyers from the USSR recognised that the sovereignty of the state extends to unlimited amounts. The USSR continued its claims for vertical 
sovereignty without a defined upper altitude limit. In 1999, British lawyers acknowledged that the United Kingdom does not have a definition of the upper limit of its airspace, but for practical purposes, it considers the highest altitude limit for airplanes as a limit. The United Kingdom has also not limited any future claims that may arise from this.

Although the US agreed with the principle of state sovereignty expressed in the Paris Convention of 1919, it did not ratify the convention. In the Air Commerce Act of 1926, the US recognised its complete sovereignty in the airspace above its land and waters. The US's opinion on the vertical limit has gradually changed. In addition, the US has recognised the right to place balloons at certain heights, although this issue was not regulated by international law. After the launch of the Sputnik in 1957, the US intended to protest against the threat to state sovereignty, but ultimately did not. It also did not recognise the need to define space. On the other hand, in order to define astronaut qualifications, the US armed forces (The US Air Force) defined the concept of "space" as a region reaching $80.4 \mathrm{~km}$ above the surface of the Earth in 2003.

\section{Legal doctrines regarding the delimitation of space and air and space activities}

Regarding the setting of the boundaries between the air and space, there are two schools: functionalists and spatialists (Kayser 1994, p. 497). Functionalists (including S. Meyer and N.M Matte, among others) are opponents of the geographical division of space and believe that the basis for the division should form international aviation law only according to the range of the aircraft. On the other hand, the Patrons deem it necessary to make such a division, because the problems of air space and space are completely different and should have separate legal regimes (Cheng 1980, pp. 323-361, Buzdugan 2007). The precursor of the functional method is M. Lemoine, who, in 1947, decided that Aviation Law defines and examines the laws and norms governing the movement and use of aircraft, as well as the resulting relations, and space law is to refer to shipping in space. The development of functional theory came from a lecture by R. Quadri in 1959, in which an Italian scientist tried to show that from the point of view of 
space activity, spaces form one inseparable whole, without division into zones. Presenting his functional understanding of territorial authority, he concluded that space activities are subject only to the authority of the state sending the space object, while excluding the power of states over which this object passes. N. M. Matte was also among the leading advocates of functional theory. According to him, space flight or space flight takes place when it involves at least one stopping somewhere else than on the surface of the Earth for peaceful, scientific or humanitarian purposes.

One of the oldest proposals for air and space demarcation is limiting vertical sovereignty to the physical point at which Space begins. However, there is no natural line between the two spaces. Another proposal is to extend the sovereignty of the state to the highest altitude at which aircraft can fly (T. von Karman determined that this occurs at the moment when this ship, moving at a speed of about $8 \mathrm{~km}$ / s, reaches a height of $83 \mathrm{~km}$, i.e. called the critical line). However, this is not a practical solution, as advanced technologies can change the maximum height (and thus extend the sovereignty of the state too much). Therefore, a suggestion was made that according to international law, the delimitation of airspace and space should be taken as the height corresponding to the lowest periphery of the artificial satellite of the Earth in orbit. There is even a view in literature that there has already been a norm of international customary law on this subject, since no state has so far protested against the placement of spacecraft into orbit around the Earth.

Some theoreticians have advocated treating the distance to which technical considerations allow the use of the area of Oman as the upper limit of the range of state sovereignty (M.M. Peng). RK Woetzel even tried to see the existence of a tacit agreement between the great powers that space begins to take place where the sphere of practicing aviation ends. M. Milde went further, considering that each state has full and exclusive sovereignty with regard to the space located above its territory up to the amount at which, according to the existing state of technical possibilities, any human activity or any activity directed by people is still possible.

Another theory concerns the perception of vertical sovereignty to the amount at which the state is able to actually exercise it. In general, the theory of effective authority coverage met with justified criticism, including from N. Matte and 
COPUOS. It is known, however, that rich countries have a greater ability to exercise control. Q. Wright came up with the idea that space, in the strict sense, should be counted from 150 miles, while the lower territorial zone should be separated by a middle-staged intermediate zone, in which the lower-ranked state would have certain powers dictated by the need to protect its safety. A Polish scientist, A. Górbiel, is in favor of defining the concept of "space boundary" in a treaty in the future and proposes that it should reach $100 \mathrm{~km}$. Factors that should be taken into account in such a delimitation, according to him, are the technical nature of space and the geophysical properties of the respective layers of the Earth's atmosphere (Górbiel 1985, pp. 150-175). The American lawyer D. Reinhardt proposes, analogically to the law of the sea, to determine the vertical limits of sovereignty (12 nautical miles limit, which is about $22 \mathrm{~km}$ ). A region of over 12 nautical miles will not be subject to state sovereignty, it will be treated like space above international waters. Devices operating over 12 miles will have to be adapted to ICAO standards. Any provision, as the author claims, regarding delimitation must be extremely simple in order to avoid problems (as in the case of the territorial sea) and easy to interpret. Nor can it violate commercial aviation rules (Reinhardt 2007, pp. 66-132, 136-137).

Under the influence of spatialist arguments, some states (the USSR for example) changed their minds and also recognised the need for delimitation (according to the USSR's 1979 proposal, the region above $110 \mathrm{~km}$ (counting from sea level) is already space). According to the USSR's representatives, space objects should have the right to fly over the territory of another state at an altitude of less than 100$110 \mathrm{~km}$ above sea level in order to reach orbit or return to Earth in the territory of the state. This proposal was sustained by Russia in 1996. In 2002, a bill on the ban on the use and development of space weapons appeared in the US. The project included, inter alia, the definition of Space as a region starting at $60 \mathrm{~km}$, but it was not accepted. Oduntan's theory provided for a multi-level principle of sovereignty (similar to the Cooper's project), with the limit of state sovereignty at an altitude of about $88.5 \mathrm{~km}$. Oduntan acknowledges that in order to ensure state security, the demarcation line should not be too high.

Difficulties with the separation of airspace and space caused practical problems, and perhaps the impossibility of precisely determining what in fact is the space nature of a specific activity related to exploration or exploitation of outer space, 
and which specific characteristics distinguish it from activities that do not have such character and are also implemented in this space. This difficulty seems insurmountable in reality, as exemplified by the space shuttle. As pointed out by M. G. Markoff, by law, certain activities may be allowed in the airspace, and prohibited in the non-atmospheric space. A good example is Art. IV OST, which prohibits the placing in space of weapons of mass destruction which can still be placed on decks of devices only moving through airspace. Some authors suggest that under the OST treaty, states do not have sovereignty in outer space. However, a satellite or spacecraft located in orbit that gives radio communication signals is subject to the jurisdictional power of the State of registration under the Treaty (Article VIII). Article VI and VII of the same treaty regulate issues related to the responsibility of states involved in space activities. Space activities carried out by non-governmental enterprises are also subject to the constant supervision of states. Satellite communications subject the concept of sovereignty to practical tests, but it seems that without rules to implement, the national regime will be ineffective (Brisibe 2004, pp. 649-687). In theory, space does not belong to anyone, but in reality, it is exploited by several countries (Salin 2001, pp. 181-186).

\section{Conclusions}

In the face of ever-evolving space technology, it is easy to notice changes in the understanding and implementation of the sovereignty of the state in airspace. This happens in different ways in different areas. A states' airspace sovereignty remains a principle whose application is still important for the security of the state, but the development of technology and the activities of states in space must have evolved in the understanding of the limits of the exercise of these sovereign rights. Meanwhile, the concepts and problems regarding the delimitation of space, or air and space activities, remain not fully explained.

Limitations of sovereignty cannot be presumed. Sometimes, however, doctrinal disputes arise in this matter (as in the case of the Bogotá declarations regarding the supremacy of equatorial states over Geostationary Orbit).

Bearing in mind, on the one hand, the difficulties of defining the upper limit of the territorial space of states, on the other hand, recognising the admission of 
the harmless passage of spacecraft in practice, and considering the content of regulations and space law projects, it should be recognised that the principles of this law will be shaped in isolation from territorial criteria, and mainly based on functional criteria.

\section{References}

Apfel, N.H., 1988. Space law. New York.

Berezowski, C., 1957. Zagadnienia zwierzchnictwa terytorialnego. Warsaw.

Berezowski, C., 1964. Międzynarodowe prawo lotnicze. Warsaw.

Buzdugan, M., 2007. Developing „Rules of the road” for space, issues of Space Traffic Management. Paper presented to Makau conference, 16-21 Apr 2007.

Brisibe, T.C., 2004. State sovereignty and aeronautical public correspondence by satellite. Journal of Air Law and Commerce, 69 (4), 649-687.

Cheng, B., 1980. The legal regime of airspace and outer space: the boundary problem. Functionalism versus spatialism. The major premises. AASL: Annals of Air and Space Law, 5, 323-361.

Durys, P. and Jasiński, F., 1999. Wybór aktów prawnych do nauki międzynarodowego prawa lotniczego i kosmicznego, Warsaw.

Journal of Laws 1968, no14, c. 82.

McDougal, G., Lasswell, H. and Vlasiĉ, I.A., 2007. Law and public order in space. The nationality of spacecraft and promotion of optimum order in space, vol. II, McGill, Montreal.

Fixel, R.W., 1948. The law of aviation, Charlottesville.

Górbiel, A., 1985. Międzynarodowe prawo kosmiczne, Warsaw.

Hermida, J., 2004. Legal basis for a national space legislation, Dordrecht.

Homburg, R., 1965. Droit de l'espace. Revue Générale de l'Air et le l'Espace, (4), 393-399.

Johnson, D.H.N., 1974. Rights in air space. In I.A. Vlasiĉ (ed), Montreal.

Jasentuliyana, N., 1997. Space law: the newest branch of international law. AASL, 22 (1), 345-346.

Kayser, V., 1994. From the sky to the stars: air lawyers and space lawyers; perspectives on future legal issues and legal teaching. AASL, 20 (1), 367-376.

Kayser, V., 1994. Aux confins de l'aire et de l'espace d'accursius a l'avion spatial. AASL, 19 (2), 497.

Kuhn, A.K., 1920. International aerial navigation and the peace conference. AJIL: American Journal of International Law, (2), 369-388.

Markoff, M.G., 1969. La delimitation de l'espace extra-atmosphériqu. Revue Générale del'Air de l'Espace, (4), 9-39. 
McDougal, G., Lasswell, H. and Vlasiĉ, I.A., 2007. Law and public order in space. The nationality of spacecraft and promotion of optimum order in space, vol. II. McGill, Montreal.

Martin, P.M., 1968. New frontier in the law of the air. In E. McWhinney, A. Bradley (eds), Leiden.

Reinhardt, D.N., 2007. The vertical limit of state sovereignty. Journal of Air Law and Commerce, (72), 66-132, 136-137.

Resolution no. 18/1962, accepted by the General Assembly of the United Nations in 1963, 1999. In P. Durys and F. Jasiński (eds), Wybór aktów prawnych do nauki międzynarodowego prawa lotniczego i kosmicznego, Warsaw.

Salin, P.A., 2001. The new global governance dialogue on international communications and outer space. In Proceeding of the forty-fourth colloquium on the law of outer space, International Institute of Space Law of the International Astronautical Federation, 1-5 Oct 2001, Toulouse, France.

Shaw, M.N., 2000. Prawo międzynarodowe. Warsaw.

Shrewsbury, M.S.M., 2003. September $11^{\text {th }}$ and the Single European Sky: developing concepts of airspace sovereignty. Journal of Air Law and Commerce, (68), 115-160.

Wassenbergh, H.A., 1978. Reality and value in air and space law. AASL. (3), 346-354.

Żylicz, M., 1960. Podstawowe elementy prawa aeronautycznego (zagadnienia wybrane). Zeszyty Prawnicze, (1), 189-190.

Miles, R. and Thränhardt, D., 1995. Migration and European Integration: The Dynamics of Inclusion and Exclusion. Fairleigh Dickinson Univ Press, New Jersey. 